\title{
Patients with high serum substance P levels previously to liver transplantation for hepatocellular carcinoma have higher risk of one-year liver transplantation mortality
}

Leonardo Lorente ${ }^{1}$, Sergio T. Rodriguez ${ }^{2}$, Pablo Sanz ${ }^{3}$, Antonia Pérez-Cejas ${ }^{4}$, Javier Padilla $^{3}$, Dácil Díaz ${ }^{5}$, Antonio González, María M. Martín², Alejandro Jiménez ${ }^{5}$, Purificación Cerro ${ }^{7}$ and Manuel A. Barrera ${ }^{3}$

${ }^{1}$ Intensive Care Unit, Hospital Universitario de Canarias, Santa Cruz de Tenerife, 38320, Spain

${ }^{2}$ Intensive Care Unit, Hospital Universitario Nuestra Señora Candelaria, Santa Cruz de Tenerife, 38010, Spain

${ }^{3}$ Department of Surgery, Hospital Universitario Nuestra Señora de Candelaria, Santa Cruz de Tenerife, 38010, Spain

${ }^{4}$ Laboratory Department, Hospital Universitario de Canarias, San Cristóbal de La Laguna, 38320, Spain

${ }^{5}$ Department of Digestive, Hospital Universitario Nuestra Señora de Candelaria, Santa Cruz de Tenerife, 38010, Spain

${ }^{6}$ Research Unit, Hospital Universitario de Canarias, San Cristóbal de La Laguna, 38320, Spain

${ }^{7}$ Transplant Unit, Hospital Universitario Nuestra Señora Candelaria, Santa Cruz de Tenerife, 38010, Spain

Correspondence to: Leonardo Lorente, email: lorentemartin@msn.com

Keywords: substance P; hepatocellular carcinoma; liver transplantation; mortality; outcome

Abbreviations: AFP: alpha-fetoprotein; AUC: area under curve; HCC: hepatocellular carcinoma; LT: liver transplantation; MELD: model for end-stage liver disease

Received: December 12, $2017 \quad$ Accepted: March 23, $2018 \quad$ Published: April 20, 2018

Copyright: Lorente et al. This is an open-access article distributed under the terms of the Creative Commons Attribution License 3.0 (CC BY 3.0), which permits unrestricted use, distribution, and reproduction in any medium, provided the original author and source are credited.

\section{ABSTRACT}

Purpose: Substance $P$ is a tachykinins family member with inflammatory effects. Higher circulating levels of substance $P$ have been found in patients with liver diseases and in patients with higher severity of liver diseases. The objective of this study was to determine whether serum levels of substance $P$ levels, prior to liver transplantation (LT) for hepatocellular carcinoma (HCC) are associated with one-year LT mortality.

Material and Methods: In this observational retrospective unicenter study were included patients with LT for HCC. Serum levels of substance P were measured before LT. The end-point of the study was one-year mortality after LT.

Results: We found that one-year survivor patients $(n=127)$ showed a lower age in liver donors $(p=0.03)$ and lower levels of serum substance $P$ levels $(p=0.003)$ than non-survivor patients $(n=15)$. Logistic regression analysis showed that serum levels of substance P (levels) were associated with one-year mortality (Odds Ratio $=1.011 ; 95 \% C I=1.004-1.018 ; p=0.002$ ) controlling for the age of the LT donor.

Conclusions: We believe that our study is the first study reporting data on circulating levels of substance P previously to LT for HCC, and an association between elevated levels of serum substance $P$ before $L T$ and mortality during the first year of $L T$.

\section{INTRODUCTION}

Hepatocellular carcinoma (HCC) is the most frequent primary hepatic malignant tumor, and is the second cause of death attributable to cancer. Liver transplantation (LT), which eliminate the hepatic tumor and treats the hepatic insufficiency, is the treatment of choice in some patients with HCC [1-7]. 
The Tachykinin family has different members as neurokinin A (NKA), neurokinin B (NKB), substance $\mathrm{P}$, and endokinins [8-16]. There are three tachykinin receptors (NK1R, NK2R, and NK3R). NKA has a preferential binding with NK2R, NKB with NK3R, and SP and endokinins with NK1R. Tachykinins are distributed by central and peripheral nervous systems, respiratory, urinary and immune systems, gut and blood vessels. Tachykinins are involved in the transmission of nociceptive responses, airway contraction, inflammation, vasodilation, plasma protein extravasation, smooth muscle contraction, and salivary secretion. Substance $\mathrm{P}$ is implicated in central and peripheral nervous systems injury, inflammatory bowel disease, psoriasis, migraine, and asthma [8-16].

Elevated circulating levels of substance $\mathrm{P}$ have been found in patients with liver diseases than in control subjects [17-23], and in patients with higher severity of liver diseases [21-23]. However, there is not published data about circulating levels of substance $\mathrm{P}$ in patients with HCC underwent to LT. Consequently, the objective of this study was to determine whether serum levels of substance P previously to LT for HCC are associated with one-year LT mortality.

\section{MATERIALS AND METHODS}

\section{Design and subjects}

In this observational retrospective unicenter study were included patients with LT for HCC in the Hospital Universitario Nuestra Señora de Candelaria (Santa Cruz de Tenerife, Spain) from January 1996 to January 2016. LT proceeded in all cases from brain death donor. The study was carried out by the approval of Institutional Review Board, and the written informed consent from the patients or their family members.

Previously, we determined serum levels of malondialdehyde [24], caspase-cleaved cytokeratin-18 [25], and sCD40L [26] in some of those patients. In the current work, serum levels of substance $P$ were analyzed to determine their association with LT mortality at one year.

\section{Variables recorded}

Child-Pugh score [27], inside Milan criteria [28] previously and after LT, model for end-stage liver disease (MELD) score [29] by hepatic function, degree of tumor differentiation, age of liver receptor, infiltration, age of liver donor, macrovascular invasion, microvascular invasion, portal hypertension (determined clinically or by hepatic venous pressure gradient), LT technique, multinodular tumor, treatment previously to LT, serum alpha-fetoprotein (AFP) levels, size nodules ABO blood type, and sex were recorded for all patients. One-year survival was the end-point of the study.

\section{Determination of serum levels of substance $P$}

Serum blood samples were obtained before LT, and serum levels of substance $\mathrm{P}$ were determined at Laboratory Department of Hospital Universitario de Canarias (La Laguna, Spain). We used a competitive enzyme immunoassay designed to measure substance $\mathrm{P}$ in serum and other biological fluids (R\&D Systems, Abingdon, UK). This immonoassay contains a synthetically derived human substance $\mathrm{P}$ peptide and has been shown to accurately quantitate this peptide. This kit can be used to determinate relative mass values for natural substance P. The assay was performed on an automatic analyser, the EVOLIS ${ }^{\text {TM }}$ System, a self contained micoroplate processor for automated enzyme immunoassay testing.Substance P kit has an intra-assay coefficient of variation (CV) of $9 \%$, an inter-assay CV of $15 \%$, and a detection limit of $25 \mathrm{pg} / \mathrm{ml}$.

\section{Statistical methods}

Frequencies and percentages were used to report categorical variables (compared between groups by chisquare test), and medians and interquartile ranges to report continuous variables (compared between groups by Mann-Whitney test). A receiver operating characteristic (ROC) curve was carried out to determine the one-year mortality prognostic capacity of serum levels of substance P. A Kaplan-Meier survival analysis was performed using one-year LT survival (dependent variable), and serum levels of substance P lower/higher than $182 \mathrm{pg} / \mathrm{mL}$ (independent variable); and this cut-off of serum levels of substance $\mathrm{P}$ was selected in basis to Youden $\mathrm{J}$ index. A logistic regression analysis was carried out to determine the association between serum levels of substance $\mathrm{P}$ and one-year mortality of LT controlling for LT donor age; and the clinical impact of the predictor variables was estimated by Odds Ratio and its $95 \%$ confidence intervals (CI). Statistical analyses were performed by SPSS 17.0 (SPSS Inc., Chicago, IL, USA) and MedCal 15.2.1 (Ostend, Belgium), and $P$-values $<0.05$ were considered statistically significant.

\section{RESULTS}

We included 142 patients in the study. Of them, 21 (14.8\%) were females, 136 (95.8\%) were inside Milan criteria previously to LT and 117 (82.4\%) after LT, 98 $(69.0 \%)$ had portal hypertension, $44(30.9 \%)$ multinodular tumor, $44(30.9 \%)$ infiltration, 7 (5.9\%) macrovascular invasion, and $30(21.1 \%)$ microvascular invasion. A total of $15(10.6 \%)$ patients dead during the first year of LT and 127 (89.4\%) were lives.

It was found that the surviving patients of one-year $(n=127)$ showed a lower age in liver donors $(p=0.03)$ and lower levels of serum substance $\mathrm{P}(p=0.003)$ than the non-survivor patients $(n=15)$ (Table 1). However, 
Table 1: Clinical characteristics of one-year liver transplantation survivor and non-survivor patients

\begin{tabular}{|c|c|c|c|}
\hline & $\begin{array}{l}1 \text { year } \\
\text { survivors } \\
\text { patients } \\
(n=127)\end{array}$ & $\begin{array}{c}1 \text { year } \\
\text { non-survivor } \\
\text { patients } \\
(n=15)\end{array}$ & $p$ \\
\hline Child-Pugh score- $n(\%)$ & & & 0.42 \\
\hline$\cdot \mathrm{A}$ & $62(48.8)$ & $10(66.7)$ & \\
\hline$\cdot \mathrm{B}$ & $36(28.3)$ & $3(20.0)$ & \\
\hline$\cdot \mathrm{C}$ & $29(22.8)$ & $2(13.3)$ & \\
\hline ABO blood type $-n(\%)$ & & & 0.91 \\
\hline$\cdot \mathrm{A}$ & $59(46.5)$ & $6(40.0)$ & \\
\hline$\cdot \mathrm{B}$ & $11(8.7)$ & $2(13.3)$ & \\
\hline$\cdot \mathrm{O}$ & $51(40.2)$ & $6(40.0)$ & \\
\hline$\cdot \mathrm{AB}$ & $6(4.7)$ & $1(6.7)$ & \\
\hline Gender female $-n(\%)$ & $21(16.5)$ & 0 & 0.13 \\
\hline Inside Milan criteria previously to LT $-n(\%)$ & $122(96.1)$ & $14(93.3)$ & 0.50 \\
\hline Inside Milan criteria after LT $-n(\%)$ & $106(83.5)$ & $11(73.3)$ & 0.30 \\
\hline Degree of tumor differentiation- $n(\%)$ & & & 0.48 \\
\hline$\cdot$ Well & $95(74.8)$ & $12(80.0)$ & \\
\hline - Moderate & $29(22.8)$ & $2(13.3)$ & \\
\hline$\cdot$ Poor & $3(2.4)$ & $1(6.7)$ & \\
\hline Multinodular tumor $-n(\%)$ & $39(31.5)$ & $5(33.3)$ & 0.99 \\
\hline Portal hypertension $-n(\%)$ & $87(65.8)$ & $11(73.3)$ & 0.99 \\
\hline Infiltration- $n(\%)$ & $40(31.5)$ & $4(26.7)$ & 0.99 \\
\hline Macrovascular invasion $-n(\%)$ & $7(5.5)$ & 0 & 0.99 \\
\hline Microvascular invasion $-n(\%)$ & $27(21.3)$ & $3(20.0)$ & 0.99 \\
\hline Transplantation technique- $n(\%)$ & & & 0.78 \\
\hline$\cdot$ By-pass & $44(34.6)$ & $6(40.0)$ & \\
\hline - Piggy back & $83(65.4)$ & $9(60.0)$ & \\
\hline Treatment previously to $\mathrm{LT}-n(\%)$ & $69(54.3)$ & $10(66.7)$ & 0.42 \\
\hline - Percutaneous ethanol injection (PEI) $-n(\%)$ & $28(22.0)$ & $7(46.7)$ & 0.054 \\
\hline - Radiofrequency ablation (RFA) $-n(\%)$ & $8(6.3)$ & 0 & 0.99 \\
\hline - Transarterial chemoembolization (TACE) $-n(\%)$ & $27(21.3)$ & $3(20.0)$ & 0.99 \\
\hline$\cdot$ Liver resection $-n(\%)$ & $3(2.4)$ & 0 & 0.99 \\
\hline$\cdot$ Mixed treatment $-\mathrm{n}(\%)$ & $3(2.4)$ & 0 & 0.99 \\
\hline MELD score - median (p 25-75) & $15(12-18)$ & $15(15-18)$ & 0.85 \\
\hline Nodules size $(\mathrm{cm})$ - median (p 25-75) & $3.0(2.0-3.5)$ & $3.2(1.7-4.6)$ & 0.70 \\
\hline Age of LT recipient (years) - median (p 25-75) & $59(52-62)$ & $56(53-62)$ & 0.92 \\
\hline
\end{tabular}


Leukocytes count-median $\times 10^{3} / \mathrm{mm}^{3}(\mathrm{p} 25-75)$

$4.90(3.60-6.25)$

$4.94(3.49-7.92)$

0.67

Albumin (g/dL) - median (p 25-75)

$3.33(2.90-4.10)$

$3.31(2.93-4.16)$

0.95

Protein (g/dL) - median (p 25-75)

$6.70(6.10-7.10)$

$6.70(5.70-7.68)$

0.86

Age of liver donor (years) - median (p 25-75)

$52(35-63)$

$62(49-72)$

0.03

Serum substance P (pg/mL)-median (p 25-75)

$138(81-210)$

$229(144-331)$

0.003

LT: liver transplantation; MELD: model for end-stage liver disease.

Table 2: Logistic regression analysis for the variables associated with one-year liver transplantation mortality

\begin{tabular}{lccc}
\hline & Odds Ratio & 95\% Confidence Interval & $\boldsymbol{p}$-value \\
\hline Serum substance P levels $>182 \mathrm{pg} / \mathrm{mL}$ & 5.773 & $1.681-19.828$ & 0.005 \\
Age of liver donor (age) & 1.050 & $1.002-1.100$ & 0.04 \\
\hline
\end{tabular}

Child-Pugh score, inside Milan criteria previously and after LT, MELD score, degree of tumor differentiation, age of liver receptor, infiltration, macrovascular invasion, microvascular invasion, portal hypertension, LT technique, multinodular tumor, treatment previously to LT, serum levels of AFP, size nodules ABO blood type, and sex were not statistically significant differences between one-year survivor and non-survivor patients (Table 1).

Logistic regression analysis showed that serum levels of substance $\mathrm{P}$ higher than $182 \mathrm{pg} / \mathrm{mL}$ were associated with one-year mortality (Odds Ratio $=5.773$; $95 \% \mathrm{CI}=1.681-19.828 ; p=0.005)$ controlling for the age of the LT donor (Table 2).

ROC analysis showed that the area under the curve of serum levels of substance P to predict one-year LT mortality was of $73 \%(95 \% \mathrm{CI}=65 \%-80 \% ; p=0.001)$ (Figure 1).

Kaplan-Meier survival analysis showed that patients with serum levels of substance P higher than $182 \mathrm{pg} / \mathrm{mL}$ had a higher risk of death during the first year of LT

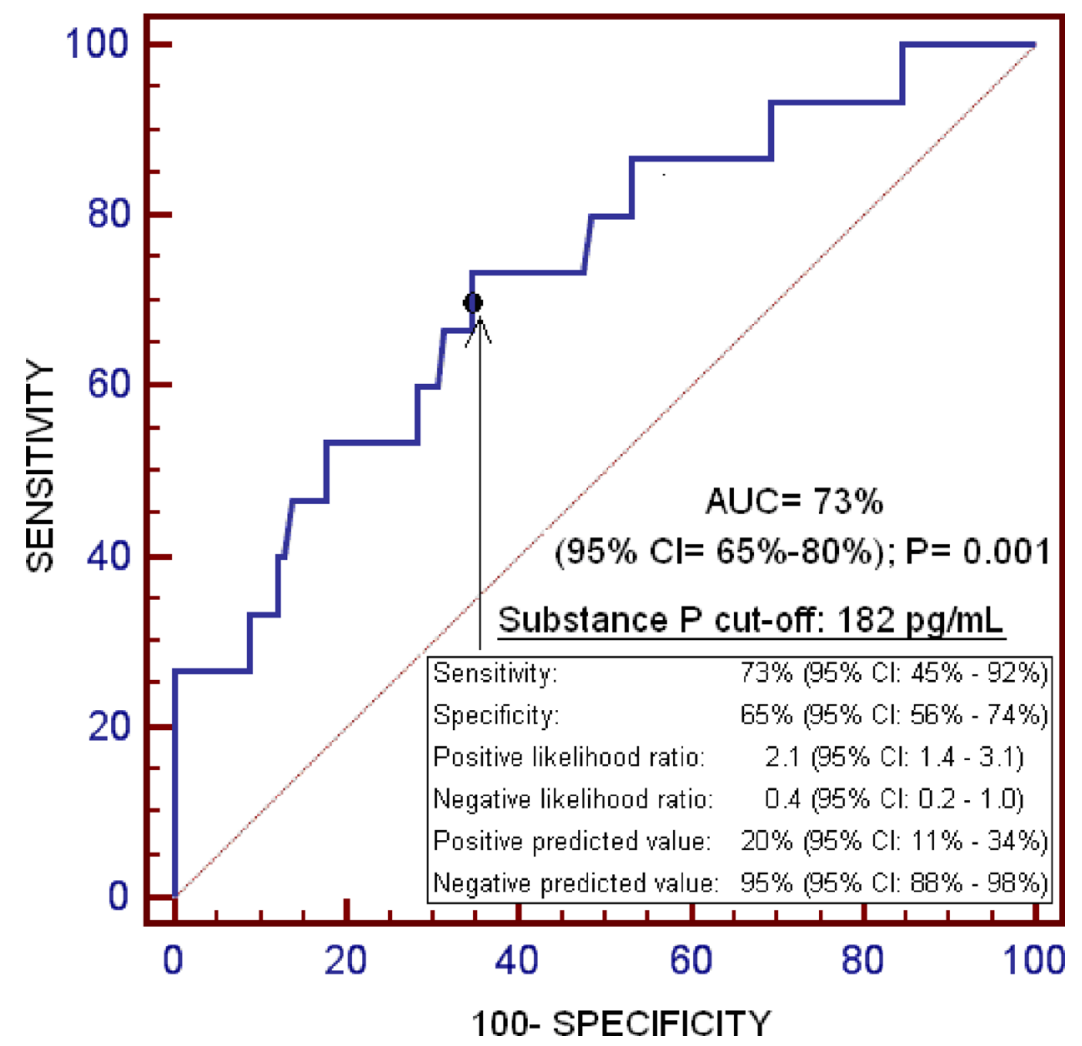

Figure 1: Receiver operation characteristic of serum substance P levels for one-year liver transplantation mortality prediction. 
$($ Hazard Ratio $=9.4 ; 95 \% \mathrm{CI}=1.73-14.27 ; p=0.003)$ than patients with lower concentrations (Figure 2).

\section{DISCUSSION}

We believe that our study is the first study reporting data on circulating levels of substance P-previously to LT for HCC, an association between elevated levels of serum substance $\mathrm{P}$ before LT and mortality during the first year after LT controlling for liver donor age, and that serum levels of substance P before LT could be used for the prognosis estimation of one-year survival after LT.

Previously, higher circulating levels of substance $\mathrm{P}$ have been found in patients with liver diseases than in healthy controls [17-23], and in patients with higher severity of liver diseases [21-23]. In one study of cirrhotic patients, plasma levels of substance $\mathrm{P}$ were higher in decompensated patients than in compensated patients, and directly correlated with Child-Pugh's score [21]. Another study with cirrhotic patients found that plasma levels of substance P directly correlated with Child-Pugh's score and inversely correlated with urinary sodium excretion [22]. In another study of patients with hepatic coma was found that plasma levels of substance $P$ inversely correlated with systemic vascular resistance and directly correlated with cardiac index, and that plasma levels of substance $\mathrm{P}$ were higher in those patients who finally died in coma [23]. Thus, the association between elevated serum levels of substance P previously to LT and mortality during the first year after LT is a new finding of this study. In addition, the findings of this investigation are in consonance with those found in other pathologies due to that elevated serum levels of substance $P$ have been associated with higher mortality in patients with brain trauma injury [30] and ischemic stroke [31].

Substance $\mathrm{P}$ participates in inflammatory response due to that is involved in the production of inflammatory cytokines as interleukin (IL)-1, IL-6 and tumor necrosis factor- $\alpha$ [32-36], prostaglandins [37, 38], nitric oxide [39], and reactive oxygen species (ROS) [40, 41]. It is possible, that non-survivor LT patients remains with higher serum levels of substance $\mathrm{P}$ than survivor patients during the first year after LT.

The use of different agents to reduce the activity of substance $\mathrm{P}$ has been proven in different pathologies and have been associated with beneficial effects. In animal models of ischemic stroke, the administration of different NK1R antagonists reduced the formation of cerebral edema, permeability of the blood-brain barrier, infarct volume, and functional deficits [42-44]. The use of NK1R antagonists has reduced brain edema and has improved functional outcome in traumatic brain injury animal models $[45,46]$. A review examined randomized controlled trials evaluating the effect of tachykinins receptors antagonist agents in patients with asthma, and found that these agents decreased the responsiveness of the airways and improved lung function [47]. Therefore, from a therapeutic perspective, the use of substance $\mathrm{P}$ antagonist agents in patients with LT for HCC could be explored to increase their survival.

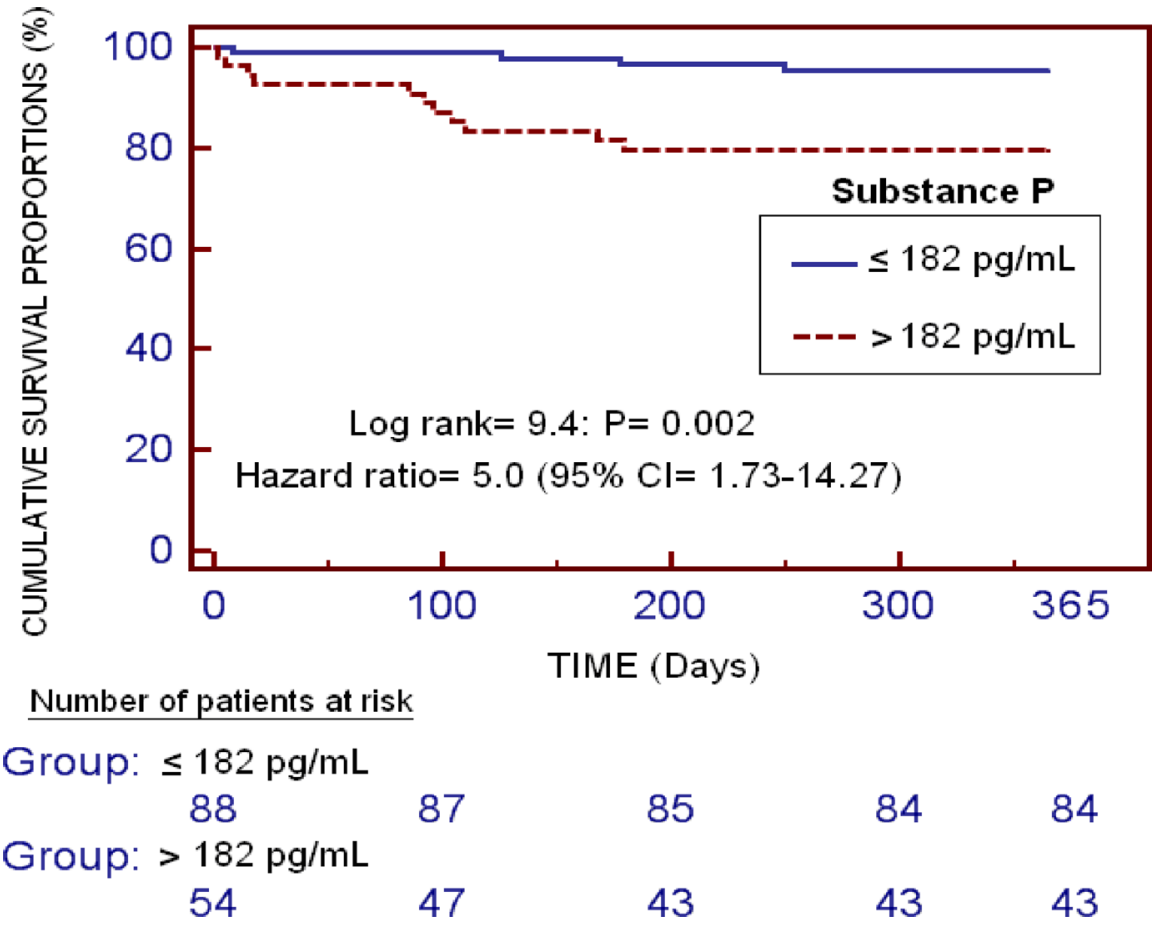

Figure 2: Kaplan-Meier survival analysis using one-year LT (dependent variable) and serum substance P levels lower/higher than $182 \mathrm{pg} / \mathrm{mL}$ (independent variable). 
We recognize some limitations of this investigation. First, there are no data on the circulating levels of inflammatory cytokines. Second, no serum samples were obtained to determine levels of circulating substance $\mathrm{P}$ during follow-up. Third, the sample size was not calculated and the non-survival group is relatively small. However was enough large to show an association between serum levels of substance P previously to LT for $\mathrm{HCC}$ and one-year liver transplantation mortality controlling for the age of LT donor. Non-survival patient group was relatively small to include other potential variables in the regression model; nevertheless, we included all variables with $p$-value lower than 0.10 in the comparison between non-survivor and survivor patient groups.

\section{CONCLUSIONS}

We believe that our study is the first study reporting data on circulating levels of substance P previously to LT for HCC, an association between elevated levels of serum substance P before LT and mortality during the first year of LT controlling for the age of liver donor, and that serum substance P levels before LT could be used for the oneyear survival prognosis estimation.

\section{Author contributions}

Conception and design: LL; Acquisition of data: LL, STR, PS, APC, JP, DD, AG, MMM, PC, MAB; Determination of serum substance P levels: APC. Analysis of data: LL, AJ. Wrote the paper: LL. All authors revised the manuscript critically for important intellectual content and made the final approval of the version to be published.

\section{CONFLICTS OF INTEREST}

None.

\section{FUNDING}

This study was supported by a grant from Instituto de Salud Carlos III (INT16/00165) (Madrid, Spain) and co-financed by Fondo Europeo de Desarrollo Regional (FEDER). The funders had no role in study design, data collection and analysis, decision to publish, or preparation of the manuscript.

\section{REFERENCES}

1. European Association For The Study Of The Liver; European Organisation For Research And Treatment Of Cancer. EASL-EORTC clinical practice guidelines: management of hepatocellular carcinoma. J Hepatol. 2012; 56:908-43. Erratum in: J Hepatol. 2012; 56:1430.
2. Clavien PA, Lesurtel M, Bossuyt PM, Gores GJ, Langer B, Perrier A, and OLT for HCC Consensus Group. Recommendations for liver transplantation for hepatocellular carcinoma: An international consensus conference report. Lancet Oncol. 2012; 13:e11-e22.

3. Verslype C, Rosmorduc O, Rougier P, and ESMO Guidelines Working Group. Hepatocellular carcinoma: ESMO-ESDO Clinical Practice Guidelines for diagnosis, treatment and follow-up. Ann Oncol. 2012 (Suppl 7); 23:vii41-8.

4. Cescon M, Bertuzzo VR, Ercolani G, Ravaioli M, Odaldi F, Pinna AD. Liver transplantation for hepatocellular carcinoma: Role of inflammatory and immunological state on recurrence and prognosis. World J Gastroenterol. 2013; 19:9174-82.

5. Bodzin AS, Busuttil RW. Hepatocellular carcinoma: Advances in diagnosis, management, and long term outcome. World J Hepatol. 2015; 7:1157-67.

6. Toyoda H, Kumada T, Tada T, Sone Y, Kaneok Y, Maeda A. Tumor markers for hepatocellular carcinoma: Simple and significant predictors of outcome in patients with HCC. Liver Cancer. 2015; 4:126-36.

7. Guerrero-Misas M, Rodríguez-Perálvarez $\mathrm{M}$, de la Mata M. Strategies to improve outcome of patients with hepatocellular carcinoma receiving a liver transplantation. World J Hepatol. 2015; 7:649-61.

8. Barnes PJ. Neurogenic inflammation in the airways. Respir Physiol. 2001; 125:145-54.

9. Almeida TA, Rojo J, Nieto PM, Pinto FM, Hernandez M, Martín JD, Candenas ML. Tachykinins and tachykinin receptors: structure and activity relationships. Curr Med Chem. 2004; 11:2045-81.

10. Pennefather JN, Lecci A, Candenas ML, Patak E, Pinto FM, Maggi CA. Tachykinins and tachykinin receptors: a growing family. Life Sci. 2004; 74:1445-63.

11. Groneberg DA, Quarcoo D, Frossard N, Fischer A. Neurogenic mechanisms in bronchial inflammatory diseases. Allergy. 2004; 59:1139-52.

12. Satake H, Kawada T. Overview of the Primary Structure, Tissue-Distribution, and Functions of Tachykinins and their Receptors. Current Drug Targets. 2006; 7:963-74.

13. De Swert KO, Joos GF. Extending the understanding of sensory neuropeptides. Eur J Pharmacol. 2006; 533:171-81.

14. Bodkin JV, Fernandes ES. TRPV1 and SP: key elements for sepsis outcome? Br J Pharmacol. 2013; 170:1279-92.

15. Steinhoff MS, von Mentzer B, Geppetti P, Pothoulakis C, Bunnett NW. Tachykinins and their receptors: contributions to physiological control and the mechanisms of disease. Physiol Rev. 2014; 94:265-301.

16. Mashaghi A, Marmalidou A, Tehrani M, Grace PM, Pothoulakis C, Dana R. Neuropeptide substance P and the immune response. Cell Mol Life Sci. 2016; 73:4249-64.

17. Trivedi M, Bergasa NV. Serum concentrations of substance P in cholestasis. Ann Hepatol. 2010; 9:177-80. 
18. El-Raziky MS, Gohar N, El-Raziky M. Study of substance $\mathrm{P}$, renin and aldosterone in chronic liver disease in Egyptian children. J Trop Pediatr. 2005; 51:320-3.

19. Li CP, Lee FY, Hwang SJ, Chang FY, Lin HC, Lu RH, Hou MC, Chu CJ, Chan CC, Luo JC, Lee SD. Role of substance $\mathrm{P}$ in the pathogenesis of spider angiomas in patients with nonalcoholic liver cirrhosis. Am J Gastroenterol. 1999; 94:502-7.

20. Uemura M, Tsujii T, Kikuchi E, Fukui H, Tsukamoto N, Matsumura M, Fujimoto M, Koizumi M, Takaya A, Kojima $\mathrm{H}$, Ishii Y, Okamoto S. Increased plasma levels of substance $\mathrm{P}$ and disturbed water excretion in patients with liver cirrhosis. Scand J Gastroenterol. 1998; 33:860-6.

21. Lee FY, Lin HC, Tsai YT, Chang FY, Lu RH, Hou MC, Li CP, Chu CJ, Wang SS, Lee SD. Plasma substance P levels in patients with liver cirrhosis: relationship to systemic and portal hemodynamics. Am J Gastroenterol. 1997; 92:2080-4.

22. Fernández-Rodriguez CM, Prieto J, Quiroga J, Zozoya JM, Andrade A, Núñez M, Sangro B, Penas J. Plasma levels of substance $\mathrm{P}$ in liver cirrhosis: relationship to the activation of vasopressor systems and urinary sodium excretion. Hepatology. 1995; 21:35-40.

23. Hörtnagl H, Singer EA, Lenz K, Kleinberger G, Lochs H. Substance $\mathrm{P}$ is markedly increased in plasma of patients with hepatic coma. Lancet. 1984; 1:480-3.

24. Lorente L, Rodriguez ST, Sanz P, Abreu-González P, Díaz D, Moreno AM, Borja E, Martín MM, Jiménez A, Barrera MA. Association between Pre-Transplant Serum Malondialdehyde Levels and Survival One Year after Liver Transplantation for Hepatocellular Carcinoma. Int J Mol Sci. 2016; 17:500.

25. Lorente L, Rodriguez ST, Sanz P, Pérez-Cejas A, Padilla J, Díaz D, González A, Martín MM, Jiménez A, Barrera MA. Prognostic value of serum caspase-cleaved cytokeratin-18 levels before liver transplantation for 1-year survival of patients with hepatocellular carcinoma. Int J Mol Sci. 2016; 17:E1524.

26. Lorente L, Rodriguez ST, Sanz P, Pérez-Cejas A, Padilla J, Díaz D, González A, Martín MM, Jiménez A, Barrera MA. High serum soluble CD40L levels previously to liver transplantation in patients with hepatocellular carcinoma are associated with mortality at one year. J Crit Care. 2017; 43:316-20.

27. Pugh RN, Murray-Lyon IM, Dawson JL, Pietroni MC, Williams R. Transection of the oesophagus for bleeding oesophageal varices. Br J Surg. 1973; 60:646-9.

28. Mazzaferro V, Regalia E, Doci R, Andreola S, Pulvirenti A, Bozzetti F, Montalto F, Ammatuna M, Morabito A, Gennari L. Liver transplantation for the treatment of small hepatocellular carcinomas in patients with cirrhosis. N Engl J Med. 1996; 334:693-699.

29. Kamath PS, Wiesner RH, Malinchoc M, Kremers W, Therneau TM, Kosberg CL, D’Amico G, Dickson ER, Kim
WR. A model to predict survival in patients with end-stage liver disease. Hepatology. 2001; 33:464-70.

30. Lorente L, Martín MM, Almeida T, Hernández M, Ramos L, Argueso M, Cáceres JJ, Solé-Violán J, Jiménez A. Serum substance $\mathrm{P}$ levels are associated with severity and mortality in patients with severe traumatic brain injury. Crit Care. 2015; 19:192.

31. Lorente L, Martín MM, Almeida T, Pérez-Cejas A, Ramos L, Argueso M, Riaño-Ruiz M, Solé-Violán J, Hernández M. Serum Levels of Substance P and Mortality in Patients with a Severe Acute Ischemic Stroke. Int J Mol Sci. 2016; 17:6.

32. Lotz M, Vaughan JH, Carson DA. Effect of neuropeptides on production of inflammatory cytokines by human monocytes. Science. 1988; 241:1218-1.

33. Laurenzi MA, Persson MA, Dalsgaard CJ, Haegerstrand A. The neuropeptide substance P stimulates production of interleukin 1 in human blood monocytes: Activated cells are preferentially influenced by the neuropeptide. Scand J Immunol. 1990; 31:529-33.

34. Ansel JC, Brown JR, Payan DG, Brown MA. Substance P selectively activates TNF- $\alpha$ gene expression in murine mast cells. J Immunol. 1993; 150:4478-85.

35. Rameshwar P, Gascón P. Substance P (SP) mediates production of stem cell factor and interleukin-1 in bone marrow stroma: potential autoregulatory role for these cytokines in SP receptor expression and induction. Blood. 1995; 86:482-90.

36. Yamaguchi M, Kojima T, Kanekawa M, Aihara N, Nogimura A, Kasai K. Neuropeptides stimulate production of interleukin-1 $\beta$, interleukin-6, and tumor necrosis factor- $\alpha$ in human dental pulp cells. Inflamm Res. 2004; 53:199-204.

37. Marriott DR, Wilkin GP, Wood JN. Substance P-induced release of prostaglandins from astrocytes: Regional specialisation and correlation with phosphoinositol metabolism. J Neurochem. 1991; 56:259-65.

38. Palma C, Minghetti L, Astolfi M, Ambrosini E, Silberstein FC, Manzini S, Levi G, Aloisi F. Functional characterization of substance $\mathrm{P}$ receptors on cultured human spinal cord astrocytes: Synergism of substance $\mathrm{P}$ with cytokines in inducing interleukin-6 and prostaglandin E2 production. Glia. 1997; 21:183-93.

39. Persson MG, Hedqvist P, Gustafsson LE. Nerve-induced tachykinin-mediated vasodilation in skeletal muscle is dependent on nitric oxide formation. Eur J Pharmacol. 1991; 205:295-301.

40. Springer J, Pleimes D, Scholz FR, Fischer A. Substance P mediates AP-1 induction in A549 cells via reactive oxygen species. Regul Pept. 2005; 124:99-103.

41. Linley JE, Ooi L, Pettinger L, Kirton H, Boyle JP, Peers C, Gamper N. Reactive oxygen species are second messengers of neurokinin signaling in peripheral sensory neurons. Proc Natl Acad Sci U S A. 2012; 109:E1578-86. 
42. Turner RJ, Helps SC, Thornton E, Vink R. A substance P antagonist improves outcome when administered $4 \mathrm{~h}$ after onset of ischaemic stroke. Brain Res. 2011; 1393:84-90.

43. Turner RJ, Vink R. NK1 tachykinin receptor treatment is superior to capsaicin pre-treatment in improving functional outcome following acute ischemic stroke. Neuropeptides. 2014; 48:267-72.

44. Yu Z, Cheng G, Huang X, Li K, Cao X. Neurokinin-1 receptor antagonist SR140333: A novel type of drug to treat cerebral ischemia. Neuroreport. 1997; 8:2117-9.

45. Gabrielian L, Helps SC, Thornton E, Turner RJ, Leonard AV, Vink R. Substance P antagonists as a novel intervention for brain edema and raised intracranial pressure. Acta Neurochir Suppl. 2013; 118:201-4.

46. Donkin JJ, Cernak I, Blumbergs PC, Vink R. A substance P antagonist reduces axonal injury and improves neurologic outcome when administered up to 12 hours after traumatic brain injury. J Neurotrauma. 2011; 28:217-24.

47. Ramalho R, Soares R, Couto N, Moreira A. Tachykinin receptors antagonism for asthma: a systematic review. BMC Pulm Med. 2011; 11:41. 